\title{
Participatory planning and quality assessment: contributions of a
} nursing management technology ${ }^{a}$

\author{
Planejamento participativo e avaliação da qualidade: contribuições de uma tecnologia de gestão em \\ enfermagem
}

\author{
Planificación participativa y evaluación de la calidad: contribuciones de una tecnología de gestión en \\ enfermería
}

\author{
Lara Vandresen ${ }^{1}$ (1) \\ Denise Elvira Pires de Pires $^{1}$ (it) \\ Maria Manuela Martins ${ }^{2}$ \\ Elaine Cristina Novatzki Forte ${ }^{1}$ (C) \\ Jorge Lorenzetti ${ }^{1}$ (10)
}

1. Universidade Federal de Santa Catarina.

Florianópolis, SC, Brasil.

2. Universidade do Porto. Porto. Portugal.
Corresponding author

Lara Vandresen.

E-mail: laravandresen@gmail.com

Submitted on $11 / 04 / 2018$.

Accepted on 01/22/2019.

DOI: $10.1590 / 2177-9465-E A N-2018-0330$

\begin{abstract}
Objective: to analyze the outcomes of participatory planning and quality assessment of the nursing care provided in a hospital ward using a nursing management technology. Method: Convergent care research focuses on research and practice intervention, developed in a hospital in southern Brazil from April to August 2016. Participatory planning and quality evaluation was performed using the PRAXIS $₫$ technology. Results: In the participatory planning, a survey of needs/problems was carried out by 33 professionals followed by 5 workshops, where mission, guiding principles, 4 priority problems, expected results, objectives and plans of activities were defined. For quality evaluation, two indicators were used: satisfaction and notification of adverse events The evaluation was carried out with 101 patients and /or relatives, predominating "great or good". Adverse events, 28 records, predominating medication errors. Conclusion: Participatory planning and quality assessment are essential to improve nursing care management and the PRAXIS $\circledast$ technological innovation has been a useful resource.
\end{abstract}

Keywords: Hospital Administration; Quality Management; Quality Indicators; Health Care; Patient Safety; Health Technologies.

\section{Resumo}

Objetivo: Analisar resultados do planejamento participativo e indicadores de avaliação da qualidade da assistência de enfermagem, em unidade de internação hospitalar com utilização de uma tecnologia de gestão. Método: Pesquisa Convergente Assistencial articulando investigação e intervenção na prática. Desenvolvida em hospital do sul do Brasil no período abril a agosto de 2016. Realizado planejamento e avaliação da qualidade com recursos da tecnologia PRAXIS®. Resultados: No planejamento participativo, realizou-se levantamento de necessidades/problemas elencados por 33 profissionais, seguido de 5 oficinas, onde foram definidas missão, princípios orientadores e 4 problemas prioritários, resultados esperados, objetivos e planos de atividades. Para avaliação da qualidade, utilizou-se dois indicadores: satisfação e notificação de eventos adversos. Realizadas 101 avaliações com pacientes e/ou familiares predominando "ótima ou boa". Os eventos adversos, 28 registros, predominando os erros de medicação. Conclusão: Planejamento participativo e avaliação da qualidade são fundamentais para melhoria da gestão dos serviços de enfermagem e a aplicação do PRAXIS $®$ constituiu-se em recurso útil.

Palavras-chave: Administração Hospitalar; Gestão da Qualidade; Indicadores de qualidade; Segurança do Paciente; Tecnologias em Saúde.

\section{Resumen}

Objetivo: Analizar resultados de la planificación participativa e indicadores de evaluación de la calidad de la asistencia de enfermería, en unidad de internación hospitalaria con utilización de una tecnología de gestión. Método: Investigación Convergente Asistencial articulando investigación e intervención en la práctica. Desarrollada en hospital del sur de Brasil en el período abril a agosto de 2016. Realizado planificación y evaluación de la calidad con recursos de la tecnología PRAXIS $®$ Resultados: En e planeamiento participativo, se realizaron levantamiento de necesidades/problemas elaborados por 33 profesionales, siguiente de 5 talleres, donde fueron definidas misión, principios orientadores y 4 problemas prioritarios, resultados esperados, objetivos y planes de actividades. Para la evaluación de la calidad, se utilizaron dos indicadores: satisfacción y notificación de eventos adversos. Se realizaron 101 evaluaciones con pacientes y/o familiares predominando "óptima o buena". Los eventos adversos, 28 registros, predominando los errores de medicación. Conclusión: La planificación participativa y la evaluación de la calidad son fundamentales para mejorar la gestión de los servicios de enfermería y la aplicación del PRAXIS® se ha constituido en un recurso útil.

Palabras clave: Administración Hospitalaria; Gestión de Calidad; Indicadores de Calidad; Seguridad del Paciente; Tecnologías en Salud. 


\section{INTRODUCTION}

Currently, health is a fundamental value for people. In addition, a debate regarding the right to health and universal access to health is on the agenda of several countries and multilateral organizations. ${ }^{1,2}$

Healthcare services are indispensable at one point or another of the human life ${ }^{1}$ and the management of such services is key to deliver safety and quality healthcare.

Deficits in the management sphere are acknowledged as one of the main problems the healthcare sector faces. This context is based on a debate regarding types of management, however, while the participatory management model is strongly accepted, it presents little effective application. ${ }^{1,3}$

Planning and quality assessment are essential to improve the management of health and nursing services. ${ }^{1}$ Among these models, the participatory model is highlighted since it adopts a philosophy of thinking and working together in order to achieve better outcomes. When a large number of people contribute to the participatory management model, work tends to be qualitatively better than when restricted to an organizational aristocracy. ${ }^{4}$ The quality of outcomes is related to the method and the planning model adopted by each institution and it is the outcome of an integrated, systemic and coherent management style conducive to a safe delivery of care while acknowledging people's rights. ${ }^{4,5}$

The acknowledgment of the importance of quality management in healthcare delivery goes back to Florence Nightingale ${ }^{6}$. The establishment of the Joint Commission on Accreditation of Hospital in the USA and the Canadian on Hospital Accreditation highlight the milestones for quality management in the health field. These commissions enabled the development of standards and criteria intended to provide tools to organizations seeking to improve the quality of healthcare delivery. ${ }^{7}$

Quality management in the healthcare field is seen as an assessment parameter, without it the service provided by healthcare facilities would be affected. The activities performed within a health facility, especially in hospitals, have potential to harm both patients and professionals. Thus, institutions, leaders and workers providing care need to implement protocols, systems and technologies in order to ensure quality and safe services. ${ }^{8}$

Quality indicators are the resources that healthcare institutions adopt to assess services since they enable understanding occurrences, analyzing tendencies or changes over time and systematically assessing the working process within facilities to support improvement in the service. The development and validation of indicators that enable benchmarking between hospitals and other institutions is a concern for hospital service managers. ${ }^{9}$

Current technological development has been intense, however, despite the great importance of hospital units in the delivery of care, technological innovations that contribute to the qualification of nursing management within such units are seldom implemented ${ }^{1}$. In this context, we highlight the University Hos- pital at the Federal University of Santa Catarina (UFSC), which holds, since 2013, a technological innovation that consists of an Inpatient Unit Management System called PRAXIS $\AA$, implemented in a pilot unit. PRAXIS $\circledR$ was developed by Lorenzetti in 2013 and has been registered by UFSC in the National Institute of Industrial Property (INPI) since 2014. It has the approval of protected patent until 2022 (Certificate No. 14196-6). ${ }^{1}$

Resources available in PRAXIS $®$ were used in this study and the focus of this intervention research were the Unit Participatory Planning (UPP) and two aspects of Quality Management: satisfaction of patients with care delivery and reporting of adverse events. These were chosen since, they include the beginning of the management process (participatory planning) and its outcome when two indicators of care quality are assessed.

Thus, this study's objective was to analyze the outcomes of participatory planning and quality indicators of the nursing care provided in a hospital ward using technological innovation resources in nursing management.

\section{METHOD}

Convergent care research (CCR) focuses on research and intervention in practice based on the interaction of researchers with a given context. CCR comprises four stages: conception, instrumentation, rigorous investigation, and analysis. ${ }^{10}$ When this method is applied to the nursing field, it enables identifying new contexts, problem solving and introduces innovation in a given setting of care practice. ${ }^{10}$

This intervention research focuses on the management of hospital inpatient units and it used the resources provided by a technological innovation directed to the management of nursing services especially intended for this type of care units. It is installed in a medical clinic of the University Hospital of the Federal University of Santa Catarina located in the South of Brazil. PRAXIS $®$ is based on the theoretical principles of participatory management (PM), the continuous improvement of performance and technological innovation with the objective to provide a positive environment for the practice of workers and patients. ${ }^{1}$ The resources provided by this technology facilitate two relevant tasks for the management of inpatient units: Participatory Planning (PP) and analysis of quality indicators.

Two strategies were used to conduct the Unit Participatory Planning (UPP). The first involved the team's context and consisted in sensitizing the workers to the importance of planning and identifying needs or problems. In this stage, which took place from April to June 2016, the researcher invited all workers from the three work shifts (morning, evening, night). A total of 33 workers consented to participate: eight nurses, one leader, and 24 nursing technicians and assistants.

The second strategy consisted in the implementation of five workshops to develop the remaining stages of the participatory planning. Twenty-two workers attended the first workshop in 
addition to the primary author and a professor with expertise in hospital management and planning. The participants assessed the systematization presented by the researchers of the data collected in the first stage. Then, they defined the mission and guiding principles, listed the four main needs or problems and elected leaders and groups responsible for conducting the remaining stages.

The other four workshops were conducted with the leaders and groups responsible for concluding the planning related to each need or problem. Five to eight individuals attended these workshops, with the support of the primary author and a management professor. They lasted 30 minutes on average. The expected outcomes, objectives and action plan for each priority need or problem were established.

To assess the quality of nursing care, two to eight indicators available in PRAXIS $₫$ were chosen: satisfaction of patients concerning the nursing care provided and adverse event reporting.

The guidelines recommended in the literature regarding the assessment of satisfaction were followed in order to ensure reliability of data. ${ }^{11}$ Hence, the participants were instructed to allow the patient and/or family members to complete the satisfaction questionnaire. The researchers or a team member who had not provided direct care to the patients and/or family members also filed the questionnaire. The form provided by the PRAXIS $\otimes$ technology includes questions concerning the assessment of nursing procedures, reasons for being satisfied or dissatisfied with the service and rating the service as poor, regular, good or excellent.

Data from the interviews conducted with 101 patients and/ or family members were systematized in a document and stored in Atlas.ti ${ }^{\circledR}$ version 8 to be coded according to the participants' statements. The Atlas.ti $\AA^{\circledR}$ consists of a tool that aids in the organization and qualitative analysis of data (Qualitative Research and Solutions). Codes were previously developed and entered in the software to categorize the interviewees' discourse. Three main categories emerged from the analysis of the interviews concerning satisfaction with: nursing services; multiprofessional team services and laboratory services.

No interviews were held with patients and/or family members in the case of internal transferences or death. Team members were sensitized to meet the need of reporting adverse events through actions performed together with the Patient Safety Center at the University Hospital, which emphasized reporting as an organizational need, but within a non-punitive approach to error reporting.

The Resolution of the Collegiate Board of Directors RDC No. 36 of 2013, from the National Agency of Sanitary Surveillance (ANVISA), establishes patient safety actions in the sphere of health services and imposes the mandatory implementation of a Patient Safety Center in these services. ${ }^{12}$

The four steps of the CCR previously mentioned guided each of the tasks selected for this study: UPP and assessment of quality of care delivery.$^{10} \mathrm{~A}$ theoretical conceptual framework was used as a reference for the analytical synthesis and theorization, linking theories and concepts of health and nursing management for hospital inpatient units management and also on quality and patient safety in the field of health.

This study is in accordance with all ethical guidelines provided by Resolutions 466/2012 and 510/2016 from the National Council of Health. All participants freely signed and informed consent forms at the different moments in time when they made part of the study and data collection was initiated only after approval was provided by the Institutional Review Board at the Federal University of Santa Catarina (No. 1.475.623).

\section{RESULTS}

This study's results were organized in two macro themes: "participatory planning" and "quality indicators".

\section{Participatory Planning}

The method provided by the PRAXIS $\AA$ technology was used to conduct the Unit Participatory Planning (UPP). This method was specially adapted for the management of inpatient units based on theories of Participatory Planning (PP) ${ }^{1}$. The stages of the PRAXIS ${ }^{\circledR}$ system include establishing the unit's mission and guiding principles; identifying needs or problems and listing expected outcomes after having established objectives and a plan of actions to achieve outcomes for each need/problem.

Considering what is proposed in the technology, two strategies were applied to conduct the UPP: sensitize the entire nursing staff (33 workers) on the importance of the PP and identifying needs and problems after conducting the five workshops.

The unit's mission "to provide excellent nursing care to the unit's patients" and the guiding principles "value the integrality of care; respect patients' peculiarities; being committed to the quality of professional practice in the work routine; value inter-professional cooperation and communication; encourage the integration of services to strengthen the Unified Health System (SUS) and comply with the code of ethics for nurses" were established in the first workshop.

The expected outcomes, objectives and plan of action for each priority need or problem were established in the remaining workshops. Since the number of professionals available were below the recommended ${ }^{13,14}$, the team elected the need or problem "workload/dimensioning" number 1 . The team established the following expected outcomes: "all hospitalized patients having their degree of dependency classified daily according to the classification tool provided by PRAXIS $\AA$; having the nursing staff sized monthly according to the outcomes obtained in that classification". Two objectives were set to tackle this problem: to classify all patients hospitalized in the unit daily to identify their degree of dependency on nursing care and establish the number of nursing workers necessary according to those classifications 
monthly. The plan of actions ranged from the qualification of workers to the classification of patients according to their degree of dependency and the calculation of the number of workers necessary, up to the development of a quarterly management bulletin directed to the hospital's chief nurse.

The second need or problem identified was "quality of life at work", the expected outcome was "having a conducive and positive working environment for most of the nursing staff'. Its objective was "to promote initiatives intended to improve the working environment of those working in the inpatient unit based on quality of life at work". The plan of action ranged from the development of a questionnaire to address quality of life at work to the establishment of opportunities to discuss occupational-health related topics with the multiprofessional team.

The outcome expected for the third need or problem "disseminate the standard operating procedures (SOP) to the staff" was: having SOP related to the work performed in the medical clinic known and available for consultation. Its objective was: to select, disseminate and assess the implementation SOP related to the work performed in the unit. The plan of actions included the identification of the SOPs available at the unit, the development and updating of new SOPs, as well as the reporting of staff's non-adherence to SOPs.

The last need or problem, "excellent healthcare delivery", focused on adverse events and satisfaction of patients with nursing care. The outcomes expected for this need or problem was: "having adverse events from this unit reported and properly addressed; identify daily and assess monthly how satisfied patients are with nursing care." The objectives of this need or problem are: "recording, assessing and addressing the reporting of adverse events that take place in the unit" and "identify the patients' satisfaction with nursing care, assess outcomes and implement improvement measures." The plan of action ranges from the use of quality indicators available in PRAXIS $®$, such as patient satisfaction with nursing care and reporting of adverse events, to the development of quarterly management bulletins to share data with the team and assess quality of care.

The team became committed to the planning, which is a process that is in continuous assessment. The UPP consisted of an intervention in practice because it encouraged critical thinking about the problems and how to solve them became a shared task.

\section{Quality Indicators}

Among the quality indicators available in PRAXIS $\otimes$, the results regarding patient satisfaction with nursing care and reporting of adverse events were analyzed from April to June 2016.

\section{Satisfaction with nursing care}

A total of 101 forms addressing the patients' satisfaction with nursing care were analyzed, 67 of which considered nursing care to be excellent, 33 rated it as good, and one rated it as regular. None of the patients interviewed between April and June 2016 considered the nursing care provided to be of poor quality. Aspects concerning the service provided by the multiprofessional team was highlighted among the reasons why patients were satisfied. Note that, even though the interview script clearly addressed the satisfaction of patients with nursing care, the respondents also mentioned aspects related to the multiprofessional team with which they were satisfied or dissatisfied. Satisfaction or dissatisfaction with support services as well as the service provided by the laboratory, nutrition services and with the unit's physical structure were also reported.

Figure 1 was developed using Atlas.ti, version 8 and it synthesizes the categories of the reasons why patients were satisfied with the care provided by the nursing staff, multiprofessional team and laboratory, it also presents some excerpts of the different respondents' discourse regarding each category analyzed.

Figure 1. Reasons for patient satisfaction with the service provided.

Source: Developed by the authors using Atlas.ti (2016).

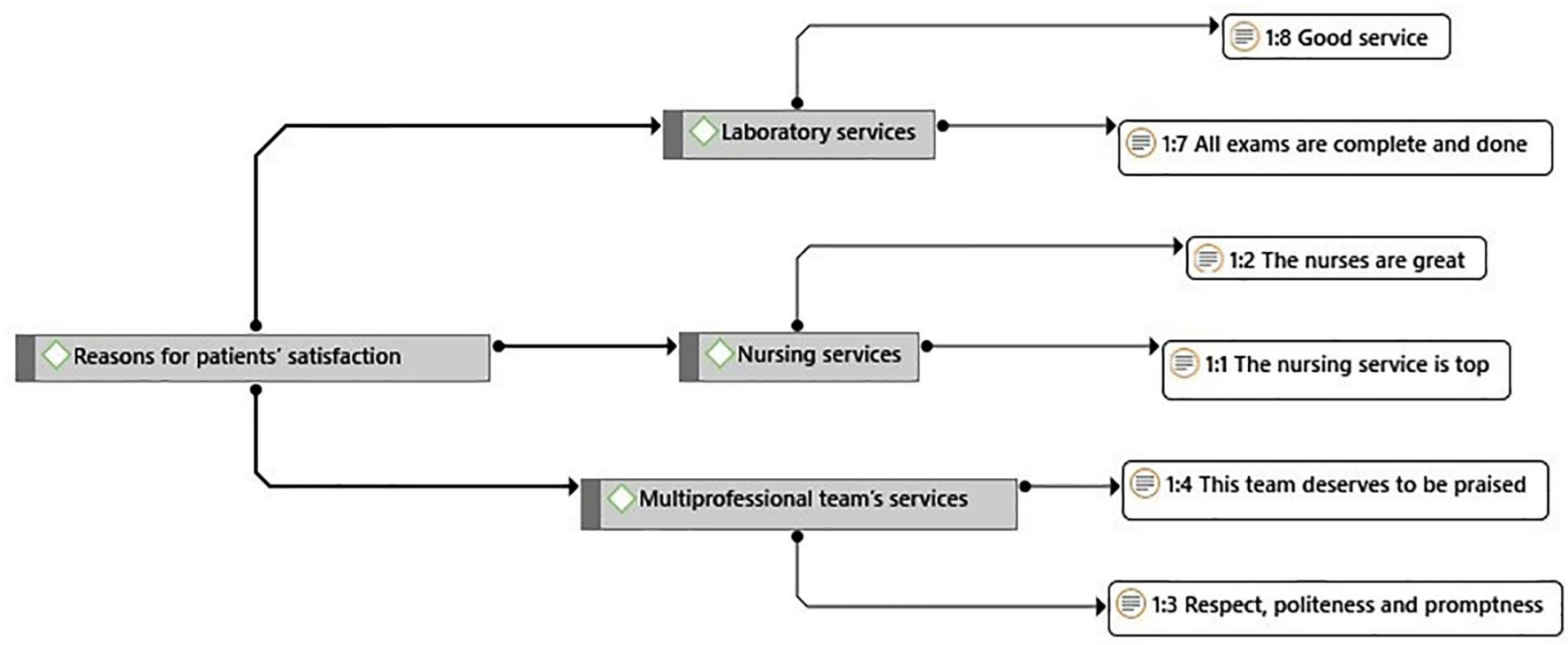




\section{Adverse Events}

The adverse events reported in this unit were related to the care provided by the nursing staff and multiprofessional team. In a total of 28 adverse events involving care, 12 refer to medication errors such as prescription, administration or infusion of medications, five were related to falling, such as falling from own height and falling from the bed. The 11 events characterized as "others" referred to the loss of peripheral venous access, expulsion of bladder catheter or nasogastric or nasoenteral tube. Figure 2 displays the types and the total number of adverse events that took place in the inpatient unit in percentage.

Figure 2. Types and number of adverse events related to care delivery, in percentage April 2016.

Source: Developed by the authors (2016).

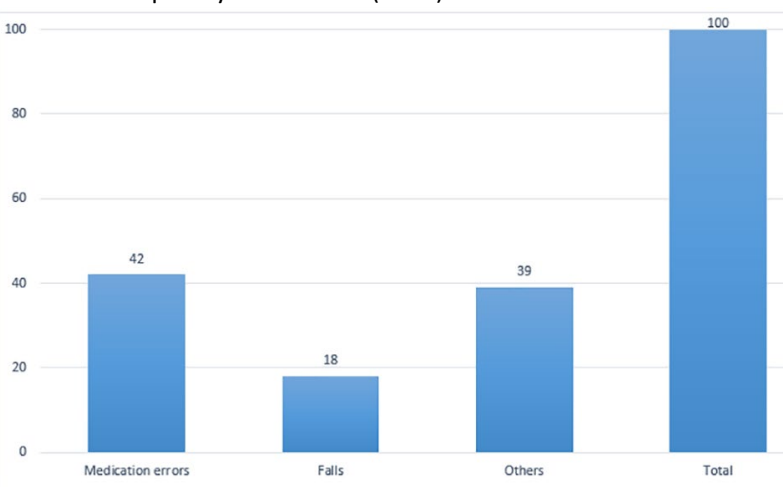

Data concerning quality indicators remained available in the electronic panel of PRAXIS $®$, on a dashboard alternating the display of data on a 50' TV placed in a nursing station. This system facilitates communication among the nursing and multiprofessional teams, patients as well as the patients' companions and families. This procedure, an intervention research, is coherent with the applied method. In addition to the intervention being implemented during the research process, the were also presented to the team through a monthly management bulletin, which provided information concerning planning and quality indicators. The CCR enabled to unveil problems that existed in the management of the context under study and, simultaneously, consisted of an intervention intended to solve those problems.

\section{DISCUSSION}

The results show that the participatory planning and the use of quality indicators such as patient satisfaction and adverse events are of significant relevance for the qualification of the management of inpatient units. This study also shows that the availability of a technological innovation in nursing management is useful to perform such tasks.

There are many challenges to overcome in terms of planning with regard to its systematic practice in inpatient units. ${ }^{15}$ This study enabled the identification of difficulties, on the part of some of the workers, with regard to seeing planning as a tool that can contribute to the organization of nursing care. Difficulties were also found with regard to the participation of team members in the development and implementation of the participatory planning; lack of time hindered the implementation of the plan of action and there was not an institutional culture to incorporate planning in inpatient units.

The fact that planning is an important tool for the organization of work and that it improves the environment of care settings has already been acknowledged. Nevertheless, there is difficulty to effectively apply it in the management of health and nursing care; there is a direct relationship between organizational culture, management model and work organization. ${ }^{16,17}$ Overcoming a perception that planning is merely "another" task to be performed in the routine of care may highly contribute to the qualification of nursing management in these important care settings. With regard to the assessment of nursing care quality, there are indicators such as the Nursing-Sensitive Quality Indicators, which monitors, among others, the satisfaction of patients with care delivery; the satisfaction among the nursing team; patient falling and skin maintenance and integrity. ${ }^{18-20}$

In this study, we monitored the patients' satisfaction with nursing care and the outcomes show that patients are mostly satisfied with the care provided; whereas complaints concerning care delivery were occasional. The patients' satisfaction with nursing care provided in the unit under study reflects the dedication and work performed by the staff during this study's period. Satisfaction can guide the decision-making process of managers and the reinforcement of positive actions or changes, transformations or the implementation of innovations in the services. ${ }^{21}$

The quality of healthcare is a priority that health institutions have pursued in order to ensure that healthcare settings are safe for professional practice and to decrease the risks to which patients are exposed. The use of performance assessment indicators of healthcare systems is a trend that has been disseminated to assess the efficiency, efficacy and effectiveness of services. ${ }^{7}$

Patient safety has received considerable attention and has stood out worldwide since the publication of the report To Err is Human: Building a Safer Health System by the Institute of Medicine. ${ }^{22}$ In 2004, the World Health Organization (WHO) established the World Alliance for Patient Safety. Nevertheless, it remains a challenge for health institutions. Despite all the initiatives health organizations and institutions have proposed, the identification of errors is a challenge because of the difficulty in accessing and reporting errors. ${ }^{23}$ In Brazil, patient safety gained the spotlight after the National Agency of Sanitary Surveillance (ANVISA) created the Brazilian Network of Sentinel Hospitals in 2002. In 2013, the National Patient Safety Program (PNSP) was launched, establishing actions to ensuring patient safety in health settings, encouraging the creation of Patient Safety Centers (NSP) within healthcare services. ${ }^{12}$

The use of indicators within the management sphere enables the identification of actual and potential problems and supports the implementation of effective actions, follow-up and the development of situations that are related to care tasks. ${ }^{9,19,24}$ Quality and safety are basic components when the intention is to meet 
the health needs of patients. Thus, it is essential to incorporate concepts of quality and safety in the organizational culture, professional behavior and performance, not only by the workers but also by those who belong to the management board of health care facilities. ${ }^{7,21}$

The adverse events that took place in the inpatient unit analyzed in this study were more significantly related to under-reporting of errors; difficulty identifying whether an event is worth reporting; and fear/stigma related to the communication and reporting of adverse events, these findings were already reported in the literature. ${ }^{26}$

An adverse event can lead a nursing worker to experience several problems, considering that it causes emotional stress, in addition to an expectation of potential ethical and legal punishments. These factors highlight the importance of implementing a safety culture, promoting the dissemination of the patient safety concept and non-punitive policies to encourage the reporting of errors. From a managerial perspective, understanding that adverse events are often directly related to system failures, rather than only to the workers' negligence, inability or incompetence, is required from the leaders of health institutions. Thus, more than seeking the ones responsible for errors and holding them accountable, fragilities within the process need to be identified and preventive measures need to be adopted. ${ }^{25}$

Studies seeking to understand the responses of workers when confronted with adverse events report that nurses and nursing technicians do not consider errors to be an intentional act as they often fail to realize the occurrence of errors. ${ }^{19,25}$ Fear arising from punitive policies, insecurity, lack of habit, and even resistance to identify and report adverse events, were identified in this study ${ }^{27}$. Nonetheless, the team was sensitized with regard to planning and discussions were promoted in this intervention research, which encouraged the team to make corrections in the processes in order to minimize errors in nursing care delivery.

Despite the current importance of implementing technological innovations in the management of inpatient units, where nursing workers play a key role in the quality of care delivered to millions of patients every year, the implementation of such innovations is limited. ${ }^{1}$ PRAXIS $®$ is a useful and promising instrument to be used in the professional practice of nursing workers and contributes to two essential tasks: work planning and assessment of the quality of results.

\section{FINAL CONSIDERATIONS}

This study's results show that planning using the participatory method is an important tool for the management of nursing care in inpatient units.

PRAXIS $®$ facilitated the analysis of the tasks concerning planning and assessment of the quality of nursing care. Note that the resources available in this technology enabled recording data daily and continuously, which in turn facilitated monitoring the performance of the unit under study. This software contributes to the organization and storing of data, overcoming a practice where recording and storing of quality indicators is not continuous and regular.

Patient satisfaction was a key element in the assessment of quality of the care provided not only by the nursing staff but also of services provided by other personnel within the hospital setting. Note that the satisfaction of patients who were transferred internally or died during the study period was not assessed, nor was that of their family members. It can be considered a limitation of this study, considering that these people's level of satisfaction could change the outcomes concerning satisfaction with care delivery.

\section{FINANCIAL SUPPORT}

Funding from Brazilian agencies from the Coordination for the Improvement of Higher Education Personnel - Brazil (CAPES) - Financing code 001.

\section{REFERENCES}

1. Lorenzetti J, Gelbcke FL, Vandresen L. Tecnologia para gestão de unidades de internação hospitalares. Texto Contexto Enferm [Internet]. 2016 Jul; [cited 2017 Jul 10]; 25(2):e170015. Available from: http://www.scielo.br/scielo.php?script=sci_arttext\&pid=S010407072016000200321\&lng=en\&nrm=iso

2. Organização das Nações Unidas. Transformando nosso mundo: a agenda 2030 para o Desenvolvimento Sustentável [Internet]. 2013; [cited 2017 Jul 10]. Centro de Informação das Nações Unidas para o Brasil (UNIC Rio) Relatório Mundial da Saúde; 2013. Available from: https://nacoesunidas. org/wp-content/uploads/2015/10/agenda2030-pt-br.pdf

3. Farias DC, Araujo FO. Gestão hospitalar no Brasil: revisão da literatura visando ao aprimoramento das práticas administrativas em hospitais. Ciênc Saúde Coletiva [Internet]. 2017 Jun; [cited 2018 Oct 9]; 22(6):1895-904. Available from: http://dx.doi.org/10.1590/141381232017226.26432016

4. Parente JRF. Planejamento Participativo em Saúde. Sanare [Internet]. $2011 \mathrm{Jan} / J u l ;$ [cited 2017 Jun 18]; 10(1):54-61. Available from: https:// sanare.emnuvens.com.br/sanare/article/view/144

5. Vidal ECF, Novais CVO, Vidal ECF, Fonseca FLA. Gestão da Qualidade nas Instituições Hospitalares. Anais do $2^{\circ}$ Congresso Brasileiro de Política, Planejamento e Gestão em Saúde [Internet]. 2013 Oct [cited 2017 Jun 18]; Belo Horizonte; 2013. p. 1-18. Available from: http://www. politicaemsaude.com.br/anais/trabalhos/publicacoes/152.pdf

6. Vargas MAO, Luz AMH. Práticas seguras do/no cuidado de enfermagem no contexto hospitalar: é preciso pensar sobre isso e aquilo. Enferm Foco [Internet]. 2010; [cited 2017 Jun 13]; 1(1):23-7. Available from: http://revista.cofen.gov.br/index.php/enfermagem/article/view/5

7. Tronchin DMR, Freitas GF, Melleiro MM. Avaliação de Serviços, Qualidade e segurança do Paciente no Setor Saúde. In: Kurcgant P. Gerenciamento em Enfermagem. 3a ed. São Paulo: Guanabara; 2016. p. 32-212.

8. Silva K, Moreira JAA, Vasconcelos LT, Oliveira LL, Coimbra CK. Gestão da qualidade total nos serviços de saúde: modelo gerencial em desenvolvimento. Rev Eletr Gestão Saúde [Internet]. 2015; [cited 2017 Jul 13]; 6(1):617-32. Available from: file:///C:/Users/susana/ Downloads/2589-Texto\%20do\%20artigo-4508-1-10-20170912.pdf

9. Cavalcante PS, Rossaneis MA, Haddad MCL, Gabriel CS. Indicadores de qualidade utilizados no gerenciamento da assistência de enfermagem hospitalar. Rev Enferm UERJ [Internet]. 2015 Nov/ Dec; [cited 2017 Jun 15]; 23(6):787-93. Available from: http:// www.e-publicacoes.uerj.br/index.php/enfermagemuerj/article/ view/7052/16181

10. Trentini M, Paim L, Silva DMGV. Pesquisa Convergente Assistencial: Delineamento provocador de mudanças nas práticas de saúde. $3 a$ ed. Porto Alegre: Moriá; 2014. 
11. Silva LVB, Monte MJ, Galvão NMS, Correia JJA. Características Qualitativas da Pesquisa Científica: Uma visão para pesquisas qualitativas e quantitativas. Id On Line Rev Psic [Internet]. 2017 May; [cited 2017 Jun 15]; 11(35):607-14. Available from: https://idonline. emnuvens.com.br/id/article/view/590/1068

12. Ministério da Saúde (BR). Agência Nacional de Vigilância Sanitária. Resolução RDC № 36 de 25 de julho de 2013. Institui ações para a segurança do paciente em serviços de saúde e dá outras providências. [Internet]. Brasília (DF): Ministério da Saúde; 2013 [cited 2017 Jun 18]. Available from: http://bvsms.saude.gov.br/bvs/saudelegis/anvisa/2013/ rdc0036_25_07_2013.html

13. Conselho Federal de Enfermagem (BR). Resolução Cofen № $543 / 2017$. Atualiza e estabelece parâmetros para o Dimensionamento do Quadro de Profissionais de Enfermagem nos serviços/locais em que são realizadas atividades de enfermagem [Internet]. Brasília (DF): Cofen; 2017. [cited $2018 \mathrm{Jul} 4$ ]. Available from: http://www.cofen.gov. br/resolucao-cofen-5432017_51440.html

14. Conselho Federal de Enfermagem (BR). Resolução Cofen №. 527/2016 - Revogada pela Resolução Cofen №543/2017. Atualiza e estabelece parâmetros para o Dimensionamento do Quadro de Profissionais de Enfermagem nos serviços/locais em que são realizadas atividades de enfermagem [Internet]. Brasília (DF): Cofen; 2016. [cited 2018 Jul 4]. Available from: http://www.cofen.gov.br/resolucao-cofenno-05272016 46348.html

15. Lorenzetti J, Oro J, Matos E, Gelbcke FL. Organização do trabalho da enfermagem hospitalar: abordagens na literatura. Texto Contexto Enferm [Internet]. 2014 Oct/Dec; [cited 2017 Sep 18]; 23(4):1104-12. Available from: http://www.scielo.br/pdf/tce/v23n4/pt_0104-0707tce-23-04-01104.pdf

16. Lorenzetti J, Lanzoni GMM, Assuiti LFC, Pires DEP, Ramos FRS. Gestão em saúde no Brasil: diálogo com gestores públicos e privados. Texto Contexto Enferm [Internet]. 2014 Apr/Jun; [cited 2017 Aug 14]; 23(2):417-25. Available from: http://dx.doi.org/10.1590/010407072014000290013

17. Rocha FLR, Marziale MHP, Carvalho MC, Cardeal SF, Campos MCT. A cultura organizacional de um hospital público brasileiro. Rev Esc Enferm USP [Internet]. 2014 Apr; [cited 2017 Aug 14]; 48(2):308-14. Available from: http://dx.doi.org/10.1590/S0080-6234201400002000016

18. SIPAGEH. Sistema de Indicadores Padronizados para Gestão Hospitalar [Internet]; 2006. Available from: http://www.projeto. unisinos.br/sipageh/index.php?option=com_content\&task=view\& $\mathrm{d}=82 \&$ Itemid=206\&menu_ativo=active_menu_sub\&marcador=191
19. Siman AG, Cunha SGS, Brito MJM. Nursing actions for patient safety in hospitals: integrative review. Rev Enferm UFPE [Internet]. 2017 Feb; [cited 2017 Oct 14]; 11(Suppl 2):1016-24. Available from: https:// periodicos.ufpe.br/revistas/revistaenfermagem/article/view/13472

20. Galhardi NM, Escobar EMA. Indicadores de qualidade de enfermagem. Rev Ciênc Méd (Campinas) [Internet]. 2015 May/Aug; [cited 2017 Aug 14]; 24(2):75-83. Available from: https://seer.sis.puc-campinas.edu.br/ seer/index.php/cienciasmedicas/article/view/2639

21. Freitas JS, Silva AEBC, Minamisava R, Bezerra ALQ, Sousa MRG Qualidade dos cuidados de enfermagem e satisfação do paciente atendido em um hospital de ensino. Rev Lat Am Enferm [Internet]. 2014 May/Jun; [cited 2017 Aug 4]; 22(3):454-60. Available from: http://www. scielo.br/pdf/rlae/v22n3/pt_0104-1169-rlae-22-03- 00454.pdf

22. Institute of Medicine (US) Committee on Quality of Health Care in America; Kohn LT, Corrigan JM, Donaldson MS, eds. To err is human: building a safer health system [Internet]. Washington: National Academies Press; 2000. Available from: https://www.ncbi.nlm.nih.gov/ books/NBK225182/

23. Forte ECN, Pires DEP, Padilha MI, Martins MMFPS. Nursing errors: a study of the current literature. Texto Contexto Enferm [Internet]. 2017 Jul; [cited 2018 Nov 2]; 26(2):e01400016. Available from: http://dx.doi. org/10.1590/0104-07072017001400016

24. Vieira APM, Kurcgant P. Indicadores de qualidade no gerenciamento de recursos humanos em enfermagem: elementos constitutivos segundo percepção de enfermeiros. Acta Paul Enferm [Internet]. 2010; [cited 2017 Aug 4]; 23(1):11-5. Available from: http://dx.doi.org/10.1590/ S0103-21002010000100002

25. Duarte SCM, Stipp MAC, Silva MM, Oliveira FT. Eventos adversos e segurança na assistência de enfermagem. Rev Bras Enferm [Internet]. 2015 Feb; [cited 2017 Aug 14]; 68(1):144-54. Available from: http:// dx.doi.org/10.1590/0034-7167.2015680120p

26. Forte ECN, Machado FL, Pires DEP. A relação da enfermagem com os erros de medicação: uma revisão integrativa. Cogitare Enferm [Internet] 2016 Jul; [cited 2017 Aug 14]; 21(no.spe):1-10. Available from: http:// revistas.ufpr.br/cogitare/article/view/43324

27. Paiva MCMS, Popim RC, Melleiro MM, Tronchim DMR, Lima SAM, Mont JCMC. The reasons of the nursing staff to notify adverse events. Rev Lat Am Enferm [Internet]. 2014 Sep/Oct; [cited 2017 Aug 14];22(5):747-54 Available from: http://dx.doi.org/10.1590/0104-1169.3556.2476

\footnotetext{
a Article resulting from the master's thesis titled "Management of Hospitalization Units: Contrition of a Technology", by Lara Vandresen, under the guidance of Denise Elvira Pires de Pires, presented to the Graduate Program in Nursing at the Federal University of Santa Catarina Catarina (PEN-UFSC).
} 